University of Nebraska - Lincoln

DigitalCommons@University of Nebraska - Lincoln

Faculty Publications from the Harold W. Manter Laboratory of Parasitology

8-1992

\title{
Origins, Diversification, and Historical Structure of the Helminth Fauna Inhabiting Neotropical Freshwater Stingrays (Potamotrygonidae)
}

Daniel R. Brooks

University of Toronto, dnlbrooks@gmail.com

Follow this and additional works at: https://digitalcommons.unl.edu/parasitologyfacpubs

Part of the Parasitology Commons

Brooks, Daniel R., "Origins, Diversification, and Historical Structure of the Helminth Fauna Inhabiting Neotropical Freshwater Stingrays (Potamotrygonidae)" (1992). Faculty Publications from the Harold W. Manter Laboratory of Parasitology. 211.

https://digitalcommons.unl.edu/parasitologyfacpubs/211

This Article is brought to you for free and open access by the Parasitology, Harold W. Manter Laboratory of at DigitalCommons@University of Nebraska - Lincoln. It has been accepted for inclusion in Faculty Publications from the Harold W. Manter Laboratory of Parasitology by an authorized administrator of DigitalCommons@University of Nebraska - Lincoln. 


\title{
ORIGINS, DIVERSIFICATION, AND HISTORICAL STRUCTURE OF THE HELMINTH FAUNA INHABITING NEOTROPICAL FRESHWATER STINGRAYS (POTAMOTRYGONIDAE)*
}

\author{
Daniel R. Brooks \\ Department of Zoology, University of Toronto, Toronto, Ontario, Canada M5S 1A1
}

\begin{abstract}
Members of the freshwater stingray family Potamotrygonidae occur throughout the major river systems of eastern South America that empty into the Atlantic Ocean. Ichthyologists have tended to assume that the ancestor of the potamotrygonids was an Atlantic marine or euryhaline stingray that dispersed into freshwater, presumably during the last marine ingression 3-5 million years ago. The helminth parasites that inhabit potamotrygonids suggest an alternative perspective on their origin. Phylogenetic and biogeographic analysis of the helminths inhabiting potamotrygonids suggest that the hosts are derived from an ancestral Pacific urolophid stingray that was trapped in freshwater by the uplifting of the Andes beginning perhaps as early as the early Cretaceous period and ending by the mid-Miocene epoch, changing the course of the Amazon River, which previously had flowed into the Pacific Ocean.
\end{abstract}

Elasmobranchs are an old and diverse group of vertebrates inhabiting areas ranging from marine to fresh water. Marine elasmobranchs retain urea and other organic substances in their blood and tissue fluids, creating an internal osmotic environment comparable to the surrounding sea water. The rectal gland supplements kidney function, secreting salt in a fluid that has twice the concentration of body fluids. Euryhaline elasmobranchs function like marine species under conditions of high salinity; however, in less saline waters their urea concentration drops to $20-50 \%$ of marine levels, and rectal gland function either is reduced or stopped (see references in Thorson et al., 1983). Some of these animals, such as the bull sharks and sawfish of Lake Nicaragua, may spend extended periods in fully freshwater habitats.

Members of the stingray family Potamotrygonidae, the only elasmobranchs permanently adapted to freshwater habitats, occur throughout the major river systems of eastern South America. They cannot concentrate urea, although they produce some of the necessary enzymes, and their rectal glands are small and apparently nonfunctional. Not even physiological conditioning can induce these rays to concentrate urea or excrete salt (Thorson et al., 1983). The highly evolved nature of stingrays, relative to sharks and skates, and the absence of totally freshwater species in

Received 29 October 1991; revised 17 January 1992; accepted 17 January 1992.

* Paper from the von Ihering Centenary Symposium on parasite biogeography and coevolution presented at the 1991 annual meeting of the American Society of Parasitologists. any other elasmobranch group, led biologists to assume that potamotrygonids are derived from marine ancestors. The presence of a rectal gland and some of the enzymes for concentrating urea has been accepted as evidence that potamotrygonids are not a particularly old group. Furthermore, ichthyologists have tended to assume that the ancestor of the potamotrygonids was an Atlantic marine or euryhaline stingray that dispersed into fresh water because potamotrygonids are restricted to rivers that empty into the Atlantic Ocean.

Brooks et al. (1981) proposed an alternative perspective of the origins of the potamotrygonids, based on a series of studies using the helminth parasites that inhabit them. They began by establishing a sequence of questions to be answered: (1) Are potamotrygonids inhabited by helminth parasites that are related to helminths inhabiting other elasmobranchs? If not, then parasite evidence could not be used to determine anything about the evolutionary origins of potamotrygonids. If the helminths inhabiting potamotrygonids were related to those found in other elasmobranchs, however, they, their phylogenetic relationships, and their host and geographic affinities might provide evidence bearing on the origins of potamotrygonids. (2) Do the helminths inhabiting potamotrygonids form monophyletic groups? If so, then the most parsimonious hypothesis is that the potamotrygonids themselves are monophyletic and that their common ancestor brought the ancestors of the various helminth groups into fresh water with it. If not, then the most parsimonious explanation is that potamotrygonids are derived from more than 1 marine ancestor. (3) What is (are) the source(s) of 
TABLE I. Geographic distribution of 23 species of parasitic worms inhabiting South American freshwater stingrays. Locality 1, upper Parana, including the lower Mato Grosso; 2, mid-Amazon, near Manaus; 3, upper Amazon, near Leticia; 4, delta of the Orinoco; 5, Lake Maracaibo tributaries; 6, mid- to lower Magdalena. Species are numbered for phylogenetic and biogeographic analysis. +, present at locality; 0 , absent at locality.

\begin{tabular}{|c|c|c|c|c|c|c|}
\hline \multirow[b]{2}{*}{ Parasite species } & \multicolumn{6}{|c|}{ Locality } \\
\hline & 1 & 2 & 3 & 4 & 5 & 6 \\
\hline 1. Acanthobothrium quinonesi & 0 & 0 & 0 & 0 & + & + \\
\hline 2. Acanthobothrium regoi & 0 & 0 & 0 & + & 0 & 0 \\
\hline 3. Acanthobothrium amazonensis & 0 & 0 & + & 0 & 0 & 0 \\
\hline 4. Acanthobothrium terezae & + & 0 & 0 & 0 & 0 & 0 \\
\hline 8. Potamotrygonocestus magdalenensis & 0 & 0 & 0 & 0 & 0 & + \\
\hline 9. Potamotrygonocestus orinocoensis & 0 & 0 & 0 & + & 0 & 0 \\
\hline 10. Potamotrygonocestus amazonensis & 0 & 0 & + & + & + & 0 \\
\hline 13. Rhinebothroides moralarai & 0 & 0 & 0 & 0 & 0 & + \\
\hline 14. Rhinebothroides venezuelensis & 0 & 0 & 0 & + & + & 0 \\
\hline 15. Rhinebothroides circularisi & 0 & 0 & + & 0 & 0 & 0 \\
\hline 16. Rhinebothroides scorzai & + & 0 & 0 & + & 0 & 0 \\
\hline 17. Rhinebothroides freitasi & 0 & + & 0 & 0 & 0 & 0 \\
\hline 18. Rhinebothroides glandularis & 0 & 0 & 0 & + & 0 & 0 \\
\hline 19. Rhinebothroides mclennanae & + & 0 & 0 & 0 & 0 & 0 \\
\hline 26. Eutetrarhynchus araya & + & + & 0 & + & 0 & 0 \\
\hline 27. Rhinebothrium paratrygoni & + & + & 0 & + & 0 & 0 \\
\hline 28. Paraheteronchocotyle tsalickisi & 0 & 0 & + & 0 & 0 & 0 \\
\hline 29. Potamotrygonocotyle amazonensis & 0 & 0 & + & 0 & 0 & 0 \\
\hline 30. Echinocephalus daileyi & 0 & 0 & + & + & 0 & 0 \\
\hline 31. Paravitellotrema overstreeti & 0 & 0 & 0 & 0 & 0 & + \\
\hline 32. Terranova edcaballeroi & 0 & 0 & 0 & + & 0 & 0 \\
\hline 33. Megapriapus ungriai & 0 & 0 & 0 & + & 0 & 0 \\
\hline 34. Leiperia gracile & + & 0 & 0 & 0 & 0 & 0 \\
\hline 35. Brevimulticaecum sp. & + & 0 & 0 & 0 & 0 & 0 \\
\hline
\end{tabular}

the helminths? The geographic distribution of their marine sister groups would provide an estimate of the general geographic area from which the ancestral potamotrygonid and its helminth fauna came. (4) What has been the pattern of diversification for the helminth fauna in potamotrygonids? For example, if they arrived relatively recently in freshwater and had speciated as a result of independent dispersal, potamotrygonids and their parasites should not show correlated patterns of speciation with organisms that evolved in the freshwater habitats. (5) And finally, how long ago did potamotrygonids arrive in freshwater habitats? Correlated biogeographic and phylogenetic patterns often can provide a robust estimate of age of groups, even in the absence of a fossil record; in fact, as I will show later, this study provides just such an example. In addition, the degree of complexity of a geographic distribution pattern for a group of species often is correlated with the length of time the group has been in an area.

Twenty-four species of parasitic worms have been found inhabiting potamotrygonids thus far. Four of the 24 parasite species listed in Table I inhabit either teleosts (Paravitellotrema overstreeti, Terranova edcaballeroi) or crocodilians
(Leiperia gracile, Brevimulticaecum sp.), and local potamotrygonids appear to have picked them up, at least on occasion (in my experience, they are not commonly found in potamotrygonids). Nineteen of the remaining 20 species of parasites are restricted to potamotrygonids (the exception being Megapriapus ungriai, the only acanthocephalan known to inhabit elasmobranchs and whose relationships to other acanthocephalans is uncertain). The closest relatives to those species inhabit marine stingrays, so it seems likely that most of the parasite groups inhabiting potamotrygonids were brought into neotropical freshwater habitats with the ancestor of the stingrays themselves.

Fourteen of the 19 species belonging to groups inhabiting elasmobranchs are members of 3 clades (Fig. 1), whereas the remaining species each represent a different clade. On the basis of this information, it would appear that the helminth fauna of potamotrygonids is an assemblage of monophyletic groups and single species, supporting the hypothesis that potamotrygonids arose from a single invasion of freshwater habitats in South America.

Phylogenetic hypotheses postulating the sister groups for some, but not all, of the helminths 
4 3

2

1

A.terezae A. amazonensis A.regoi A. quinonesi

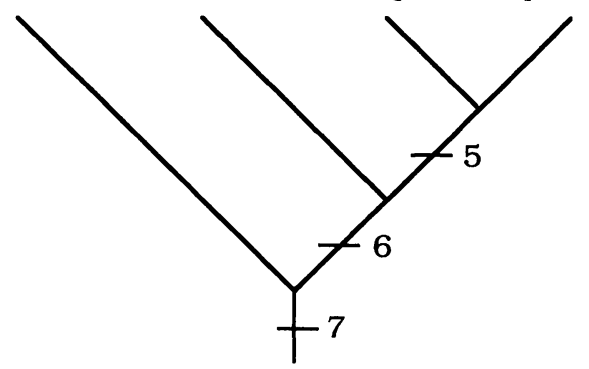

A
10

P. amazonens
9

P. orinocoensis

P. magdalenensis

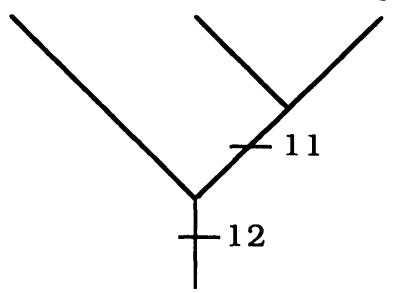

B

13

14

15

16

17

18

19

$R$. moralarai $R$. venezuelensis $R$. circularisi

R. scorzai R. freitasi

R. glandularis

R. mclennanae
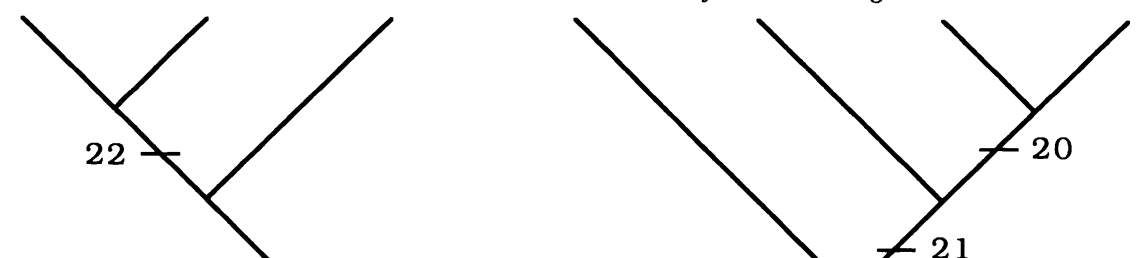

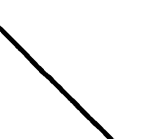
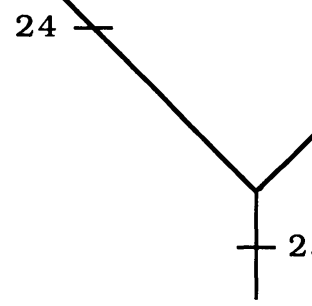

25

C

FIGURE 1. Phylogenetic trees for Potamotrygonocestus, the species-group of Acanthobothrium inhabiting potamotrygonid stingrays, and Rhinebothroides, coded for Brooks parsimony analysis (numbers above species names represent extant species; numbers above nodes indicate the phylogenetic relationships among extant species; see Brooks and McLennan [1991] for discussion of the method). A. Species group within Acanthobothrium. B. Species within Potamotrygonocestus. C. Species within Rhinebothroides.

inhabiting potamotrygonids indicate that the helminth fauna of potamotrygonids arose in the Pacific Ocean, and that many of the closest relatives of the helminth fauna of potamotrygonids inhabit urolophid stingrays. This suggests that the ancestor of the potamotrygonids was a marine urolophid living in the Pacific Ocean. This observation, by itself, is troublesome, because no potamotrygonid is known from river systems that empty into the Pacific Ocean. Consideration of the pattern of diversification for the helminth species inhabiting potamotrygonids provides additional relevant information.

The geographic distribution patterns for the parasites of potamotrygonids are complex; some of the parasite species appear to be restricted to single river systems whereas others are more widespread (Table I). Table II is a data matrix for 6 localities based on the phylogenetic relationships and distributions of the stingray helminths. Phylogenetic analysis of the data matrix derived using parasites and their phylogenetic 
TABLE II. Matrix listing 6 river systems in eastern South America and the binary codes representing the phylogenetic relationships for members of the helminth parasite groups inhabiting freshwater stingrays residing in those areas. Presence of a species in an area is indicated by 1 for the number associated with the species in Table I, plus 1 for each number indicating the relative phylogenetic relationships among members of Acanthobothrium, Potamotrygonocestus, and Rhinebothroides in Figure 1.

\begin{tabular}{lc}
\hline \multicolumn{1}{c}{ Area } & Binary code \\
\hline $\begin{array}{l}\text { Leticia, upper } \\
\text { Amazon } \\
\text { Manaus, middle } \\
\text { Amazon }\end{array}$ & 00100110010100100000000110011100000 \\
Upper Parana & 00000000000000001000101011100000000 \\
$\quad$ River & 01011110101101010011111111101000111 \\
Orinoco Delta & 0100111011110101010011111100101100 \\
Lake Maracaibo & 10001110010101000000010110000000000 \\
Magdalena River & 10001111001110000000010110000010000 \\
\hline
\end{tabular}

relationships as characters (a method proposed by Brooks [1981] and named Brooks parsimony analysis or BPA by Wiley [1988]; see Brooks and McLennan [1991] for discussion of the method) produces the area cladogram shown in Figure 2.
This area cladogram has a consistency index of $81 \%$, supporting a qualitative assessment that approximately $80 \%$ of the species occur in these areas as a result of common phylogenetic history.

On the basis of this initial analysis, the upper Parana, Orinoco, and Maracaibo localities appear to be composite areas. Recoding the data matrix, separating the upper Parana, the Orinoco, and Lake Maracaibo into multiple areas (Table III), and performing a phylogenetic analysis of this matrix, produces a new area cladogram (Fig. 3) with a consistency index of $91 \%$. This new area cladogram highlights 5 evolutionary components that have contributed to this helminth fauna. The first component is the historical geological, or vicariant, backbone linking the upper Amazon, upper Parana, Orinoco, and Magdalena areas. These areas all contain species whose phylogenetic relationships correspond to a common set of biogeographic relationships. The remaining components of the parasite distribution patterns involve 4 sequences of dispersal from these areas along the following routes: from the upper Amazon into the Orinoco and Maracaibo areas; from the upper Parana to the mid-

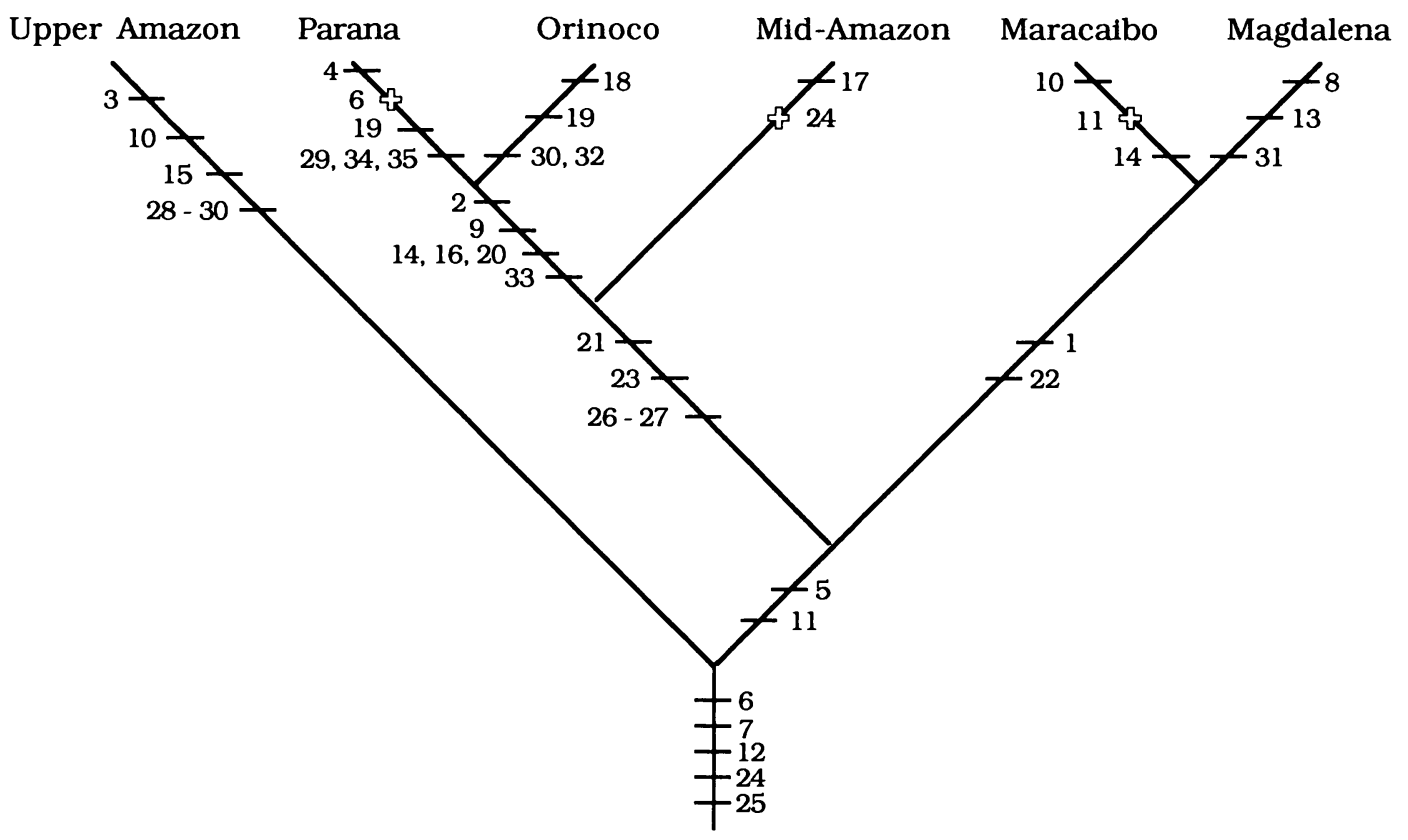

FIGURE 2. Area cladogram depicting relationships among the upper Amazon, upper Parana, middle Amazon, Orinoco, Maracaibo, and Magdalena areas based on the phylogenetic relationships of the helminths known to inhabit freshwater stingrays in those areas. Numbers represent codes for species of Potamotrygonocestus, the species group of Acanthobothrium inhabiting potamotrygonid stingrays, and Rhinebothroides and their phylogenetic relationships (1-25), plus taxa represented by single species (26-35) (see Fig. 1 and Table I). +, putative secondary absence of the taxa represented by the number(s) accompanying the + . 
TABLE III. Matrix listing 6 river systems in eastern South America and the binary codes representing the phylogenetic relationships for members of the helminth parasite groups inhabiting freshwater stingrays residing in those areas, based on duplicating the upper Parana River, Orinoco River delta, and Lake Maracaibo areas 3 times following the method described by Brooks and McLennan (1991). Presence of a species in an area is indicated by 1 for the number associated with the species in Table I, plus 1 for each number indicating the relative phylogenetic relationships among members of Acanthobothrium, Potamotrygonocestus, and Rhinebothroides in Figure 1. ?, taxon not known from the area.

\begin{tabular}{|c|c|}
\hline Area & Binary code \\
\hline $\begin{array}{l}\text { Leticia, upper } \\
\text { Amazon (MA) }\end{array}$ & 00100110010100100000000110011100000 \\
\hline $\begin{array}{l}\text { Upper Parana River } \\
\text { (P1) }\end{array}$ & $00010011 ? ? ? ? ? 0001000000101000100111$ \\
\hline $\begin{array}{l}\text { Upper Parana River } \\
\text { (P2) }\end{array}$ & 0100111010110100000001011000000000 \\
\hline $\begin{array}{l}\text { Upper Parana River } \\
\text { (P3) }\end{array}$ & 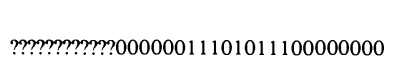 \\
\hline $\begin{array}{l}\text { Manaus, mid-Amazon } \\
\text { (UA) }\end{array}$ & 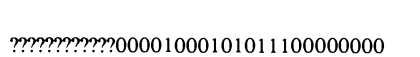 \\
\hline Orinoco Delta $\left(\mathrm{O}_{1}\right)$ & 010011101011 ?????????????0000001100 \\
\hline Orinoco Delta $\left(\mathrm{O}_{2}\right)$ & ???????00101??????????????1100000000 \\
\hline Orinoco Delta $\left(\mathrm{O}_{3}\right)$ & 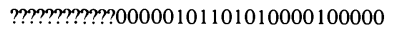 \\
\hline Orinoco Delta $\left(\mathrm{O}_{4}\right)$ & 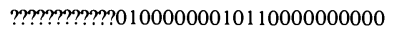 \\
\hline $\begin{array}{l}\text { Lake Maracaibo } \\
\left(\mathrm{Mar}_{1}\right)\end{array}$ & 1000111 ??????????????????0000000000 \\
\hline $\begin{array}{l}\text { Lake Maracaibo } \\
\qquad\left(\mathrm{Mar}_{2}\right)\end{array}$ & 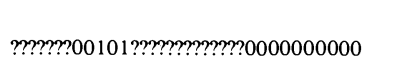 \\
\hline $\begin{array}{l}\text { Lake Maracaibo } \\
\left(\mathrm{Mar}_{3}\right)\end{array}$ & 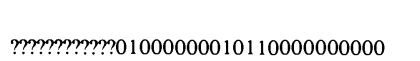 \\
\hline $\begin{array}{l}\text { Magdalena River } \\
\text { (Mag) }\end{array}$ & 10001111001110000000010110000010000 \\
\hline
\end{tabular}

Amazon to the Orinoco; from the upper Parana to the Orinoco; and from the Orinoco to the upper Parana. Such complex distribution patterns also support the conclusion that potamotrygonids have been in the neotropics for a long time.

The question of how long ago the ancestor of the potamotrygonids arrived in neotropical freshwater habitats can be approached from several perspectives. Assumptions about the evolutionary sequence of osmoregulatory modifications and observations of current geographic distribution led many ichthyologists to think that potamotrygonids were the recently derived descendants of marine stingrays. The most common evolutionary scenario postulated that the potamotrygonid ancestor moved from the Atlantic Ocean into the Amazon basin during the marine ingression of the Pliocene epoch 3-5 million years ago. Subsequent to this invasion, a population was isolated from the ancestor, progressively adapting to fresh water and spreading throughout South America by stream capture. The area cladogram (Fig. 3), however, is consistent with the geographic distribution patterns of endemic members of the fish fauna, many of whose members have fossil representatives reaching back into the Mesozoic era. It is congruent also with hypothesized geological history of the region, which links the origins of the major South American river systems with the uplifting of the Andes beginning early in the Cretaceous period, especially the reversal of flow of the Amazon in the mid-Miocene epoch (see Brooks et al. [1981] and Windley [1986] for discussion and references to the geological evidence supporting this interpretation; see Fig. 4 for a pictorial representation of the biogeographic history suggested by the area cladogram). It appears, then, that potamotrygonids are not relatively recent invaders of the neotropics.

The geography of South America prior to the mid-Miocene epoch differed in three significant ways from what we see today: Africa and South America were joined (i.e., there was no Atlantic Ocean at the mouth of the Amazon), the Andes began sweeping upward from the south beginning in the early Cretaceous period and moving northward, and the Amazon River flowed into the Pacific Ocean until the mid-Miocene epoch, when it was blocked by Andean orogeny, becoming an inland sea and eventually opening to the Atlantic Ocean. Thus, if potamotrygonids are a relatively old component of neotropical freshwater diversity east of the Andes, they must have come from the Pacific Ocean, which is today west of the Andes. If this is the case, the parasites inhabiting potamotrygonids, or their closest relatives, should inhabit marine stingrays whose geographic distribution is consistent with a hypothesis that the group originated as a result of marine invasion of South America no later than the mid-Miocene epoch.

Enlarging the spatial scale of this study to include the geographic distribution of the marine relatives of the parasites inhabiting potamotrygonids provides additional support for the hypothesis that these stingrays and their parasites originated from marine ancestors that were isolated in South America from the Pacific Ocean by the Andean orogeny. The closest relatives of the parasites inhabiting potamotrygonids occur in Pacific marine (primarily urolophid) stingrays, and those members of 2 groups for which phylogenetic hypotheses exist appear to exhibit circum-Pacific rather than trans-Pacific distribu- 


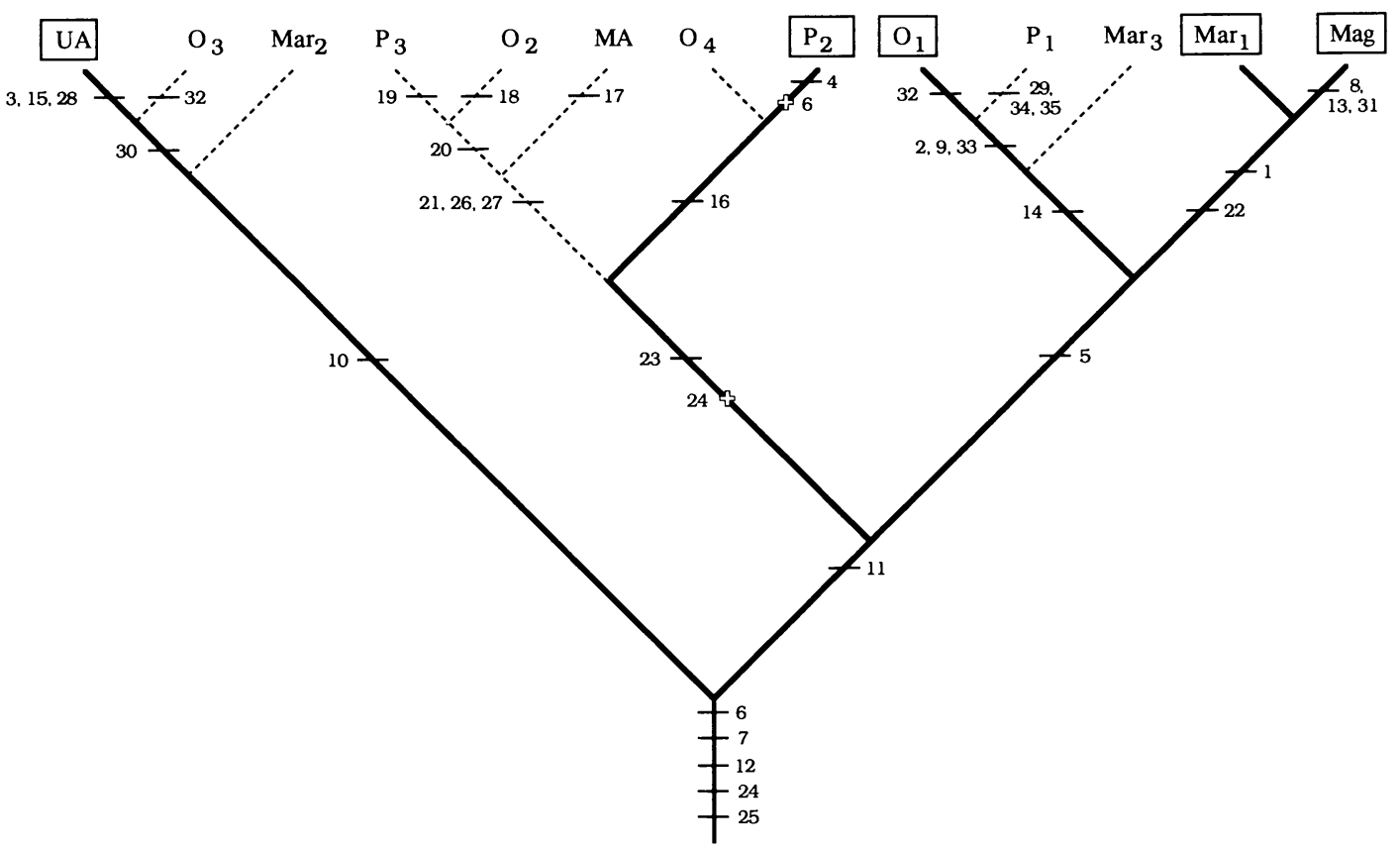

FIGURE 3. Area cladogram depicting relationships among the upper Amazon, upper Parana, middle Amazon, Orinoco, Maracaibo, and Magdalena areas based on the phylogenetic relationships of the helminths known to inhabit freshwater stingrays in those areas, produced by duplicating composite areas according to the Brooks parsimony analysis method described by Brooks and McLennan (1991). UA, upper Amazon; MA, middle Amazon; O, Orinoco; Mar, Maracaibo; Mag, Magdalena; P, Parana. Numbers represent codes for species of Potamotrygonocestus, the species group of Acanthobothrium inhabiting potamotrygonid stingrays, and Rhinebothroides and their phylogenetic relationships (1-25), plus taxa represented by single species (26-35) (see Fig. 1 and Table I). +, Putative secondary absence of the taxa represented by the number(s) accompanying the + . Solid lines, putative vicariant events; dashed lines, putative dispersal events.

tion patterns (Brooks et al., 1981; Brooks and Deardorff, 1988). A similar Pacific origin has been suggested for Amazonian freshwater anchovies (Nelson, 1984) and possibly for neotropical fresh water needlefish (Collette, 1982). In addition, each of the parasite species inhabiting potamotrygonids probably requires a mollusc or arthropod intermediate host, so it seems likely that mollusc and arthropod species derived from marine ancestors also moved into neotropical freshwater habitats along with the ancestor of the potamotrygonids.

As a consequence of this study and the others cited above, we now recognize the possibility that a sizeable component of current neotropical freshwater diversity might be derived from $\mathrm{Pa}$ cific marine ancestors. Because the uplifting of the Andes has rendered this portion of the neotropical biota nonrenewable, we should be interested in the conservation status of potamotrygonids. This is especially true now that potamotrygonids have become popular in the tropical fish trade.
Finally, I suggested above that correlations of geographic distribution patterns and phylogenetic relationships of helminths could provide a robust estimate of the age of origin for a group, even in the absence of a fossil record. A decade after the first proposal of Pacific origins of the potamotrygonids, potamotrygonid fossils have been collected recently from deposits of the midMiocene epoch in the Amazonian portion of Peru (Frailey, 1986) and Colombia (J. Lundberg, pers. comm.). Thus, this study represents a graphic empirical example of the utility of combining parasite phylogeny and historical biogeography to answer questions about evolutionary origins in the manner first envisioned by von Ihering, Kellogg, Harrison, and Johnston, amplified by Metcalf, and kept alive by Manter until the advent of modern methods of phylogenetic systematics (see Klassen, 1992).

\section{ACKNOWLEDGMENTS}

Studies of potamotrygonids and their helminths during the past $17 \mathrm{yr}$ have been made 


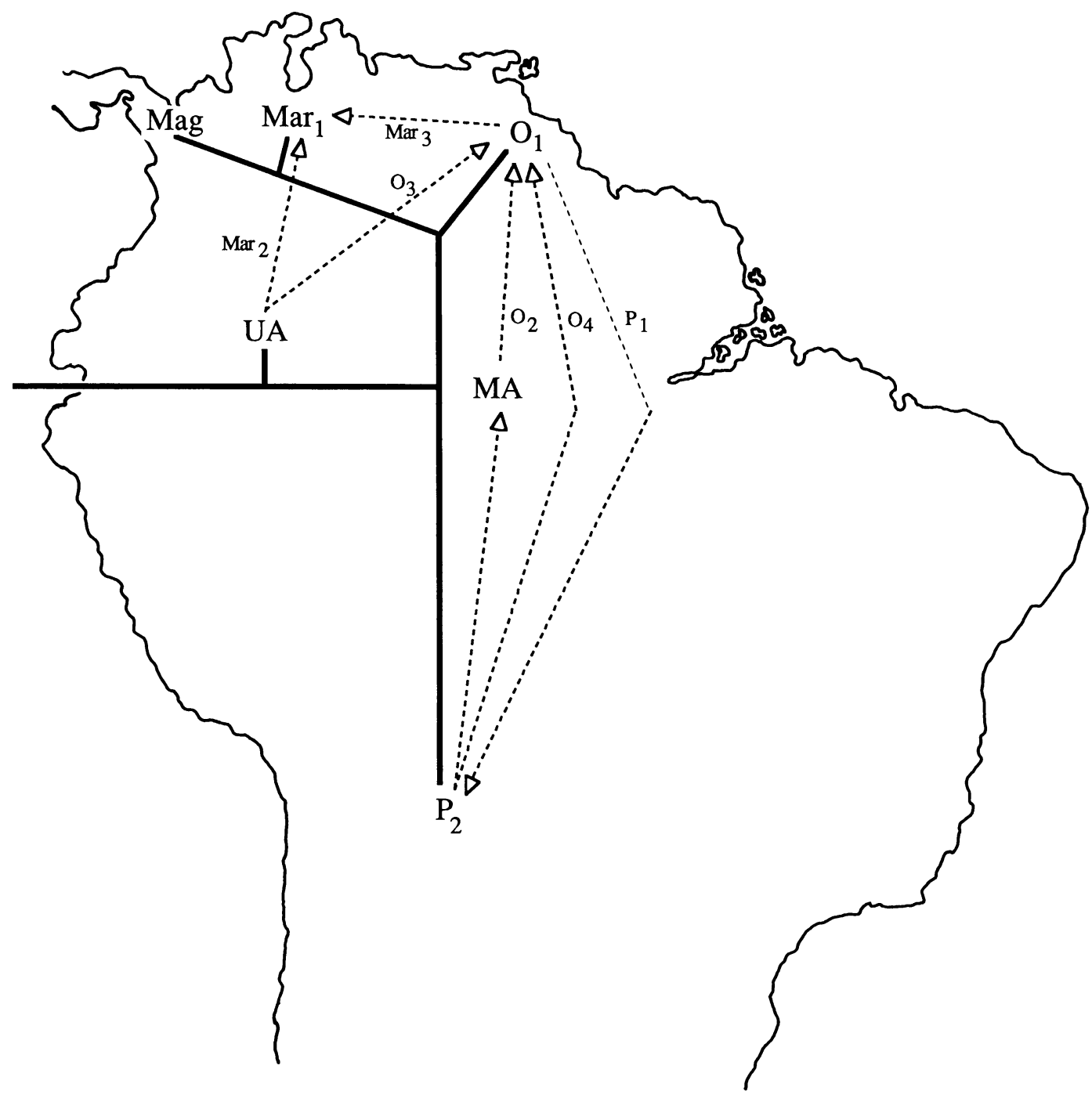

FIGURE 4. Map of South America showing complex patterns of evolutionary diversification for the helminth fauna of potamotrygonid stingrays. Heavy solid lines, putative vicariant elements; dashed lines, putative dispersal elements. UA, upper Amazon; O, Orinoco; MA, middle Amazon; Mar, Maracaibo; Mag, Magdalena; P, Parana.

possible by financial support from the National Geographic Society, the Natural Sciences and Engineering Research Council of Canada, the Conselho Nacional de Desenvolvmento Cientifico e Tecnologico of Brazil, and the National Science Foundation of the U.S.A. and by cooperation from the following governmental agencies: Colombia-Instituto de Desarollo de los Recursos Naturales (INDERENA); BrazilConselho Nacional de Desenvolvmento Cientifico e Tecnologico (CNPq) (EMBRAPA); Paraguay-Ministerio de Agricultura y Ganaderia; Venezuela-Ministerio de Agricultura y Cria, In- stituto de Zoologia Tropical of the Universidad Central de Venezuela, Universidad de Zulia, and Division de Investigaciones sobre Contaminacion de Ambiental (DISCA). In addition, collaborative efforts involving the following people have been invaluable: U.S.A. - Reeve M. Bailey, Jonathan Baskin, C. J. D. Brown, Ronald Campbell, Murray Dailey, Thomas Deardorff, Dennis M. Devaney, John Lundberg, Robert Martin, Tom Mattis, Monte Mayes, Phillip W. Myers, Robin Overstreet, John E. Randall, Gerald Schmidt, Jeffrey M. Taylor, Jamie E. Thomerson, Thomas Thorson; Brazil-J. F. R. Amato, Joao B. Catto, 
Marcello Knoff, Ricardo Rosa; Colombia-Orlando Mora Lara, Augusto Samper M., Alvaro Boada Guarin, Guillermo Quinones Gonzalez, Adolfo Baron Porras, Consuelo Teran, James Durkin, James M. Kapetsky, David A. Conroy, Hans Heinrich, Alberto Villaneda, Mike Tsalickis, William Mackay, and Dean Hendrickson; Paraguay-Hernando Bertoni, Antonio Torres, Juan Pio Rivaldi, Phil and Peg Myers, Ana Aurora Galli, Erik Raynears, Philippe Legris, Wilfredo Richter, and Bruno Ruggero Fornells; Uruguay-Raul Vaz-Ferreira, Hebert Nion, Alex Schwed Olin; and Venezuela-Francisco Mago Leccia, Antonio Rios, Hector Barrios, Jose Mosco M., Alfredo Gomez G., Donald Taphorn, Craig Lilyestrom, Eric Sutton.

\section{LITERATURE CITED}

BROOKS, D. R. 1981. Hennig's parasitological method: A proposed solution. Systematic Zoology 30: 229-249.

, AND T. L. DEARDORFF. 1988. Rhinebothrium devaneyi n. sp. (Eucestoda: Tetraphyllidea) and Echinocephalus overstreeti Deardorff and Ko, 1983 (Nematoda: Gnathostomatidae) in a thorny back ray, Urogymnus asperrimus, from Enewetak Atoll, with phylogenetic analysis of both species groups. Journal of Parasitology 74: 459-465.

, AND D. A. McLennan. 1991. Phylogeny, ecology and behavior: A research program in comparative biology. University of Chicago Press, Chicago, 440 p.
, T. B. Thorson, AND M. A. MAYes. 1981. Freshwater stingrays (Potamotrygonidae) and their helminth parasites: Testing hypotheses of evolution and coevolution. In Advances in cladistics: Proceedings of the first meeting of the Willi Hennig Society, V. A. Funk and D. R. Brooks (eds.). New York Botanical Garden, New York, p. 147-175.

Collette, B. B. 1982. South American needlefishes of the genus Potamorrhaphis (Beloniformes: Belonidae). Proceedings of the Biological Society of Washington, D.C. 95: 714-747.

Frailey, C. D. 1986. Late Miocene and Holocene mammals, exclusive of Notoungulata, of the Rio Acre region, western Amazonia. Contributions to Science of the Natural History Museum of Los Angeles 364: 1-46.

Klassen, G. 1992. Coevolution: A history of the macroevolutionary approach to studying hostparasite associations. Journal of Parasitology 78: 573-587.

Nelson, G. 1984. Identity of the anchovy Hildebrandichthys setiger with notes on relationships and biogeography of the genera Engraulis and $\mathrm{Ce}$ tengraulis. Copeia 1984: 422-427.

Thorson, T. B., D. R. Brooks, AND M. A. Mayes. 1983. The evolution of freshwater adaptation in stingrays. National Geographic Society Reports 15: 663-694.

WileY, E. O. 1988. Parsimony analysis and vicariance biogeography. Systematic Zoology 37: 271290.

WindLEY, B. F. 1986. The evolving continents, 2nd ed. John Wiley \& Sons, New York, 404 p. 